\title{
原著 VII
}

\section{経過からみた潰瘍性大腸炎の特徵}

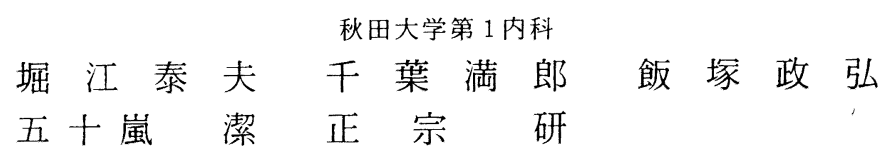

当教室で経験した潰瘍性大腸炎53例の特徵を発症からの経過年数と結びつけて検討した 結果, (1) 重症化例 は 9 例延べ12例で，いずれも発症 5 年以内にみられた. (2) 難治化例は 10 例で, このうち 9 例は発症 5 年以内 にみられた。 (3)手術例は 7 例で, 癌合併, 癌化の 2 例を除いた 5 例は 5 年以内に手術された。 (4)経過観察期 間に対する入院月数㳉, 発症 5 年以降の症例では， 5 年以内の症例に比較して，著しく短かった。 (5)入院率 は，発症 1 年目 $77.4 \%(41 / 53)$ で最も多く，その後漸減し，5 年目は9.7\%であった。 それ以降は $0 \sim 20 \%$, であった. (6) 5 年以上経過例では， 5 年目の時点と比較して治療薬が減少する例が多かった。 このことから 潰瘍性大腸炎では, 発症 5 年以内の症例では, 重症化, 難治化, 手術適応に留意すること, 5 年以降の症例 では, cancer surveillance に留意することが重要と思われた.

索引用語 : 潰瘍性大腸炎, 長期管理, 重症化, 難治化, 手術

\section{I.はじめに}

潰瘍性大腸炎（以下 UC, ulcerative colitis）では従 来内科的に治療されることが多かったが，長期にわたる 管理のため社会的制約が大きく，最近では手術術式の進 歩と相俟って, 重症例, 難治例では比較的早期の段階で 手術されることが少なくない，したがって内科医にとっ ては, 手術適応の時期を正しく判断することがきわめて 重要な問題である.われわれは教室例について重症化, 難治化が UC の経過の中でどの時期におこり,手術がい つ行われたかを retrospective に検討したので報告する.

\section{II. 対象と方法}

対象 は秋田大学第一内科で 1972年 1987年の 15年間 に, 入院または外来で治療された UC 53症例である。 そ の内訳注男性20例, 女性33例, 男女比 $1: 1.7$, 発症時年 齢14 69歳（平均33.9歳）であった. これらの症例を発 症からの経過年数でみた場合, 5 年以下観察例 26 例の発 症時年齢は14 69歳 (平均 35.2 歳), 経過観察月数は $4 \sim$ 60 力月 (平均 31.1 力月), 5 年以上観察例 27 例の発症時 年齢は 15 58歳 (平均 32.7 歳), 経過観察月数は66 216 カ月（平均113.9力月）であった (Table 1).

重症例について重症化した時期, 難治例について難治 化した時期，手術症例については施行時期と適応理由に ついて検討した. ついで入院症例については, 経過年数
別入院時重症度, 経過年数別入院率 (年時別入院症例数 $/$ 年時別総症例数) を検討した. さらに 5 年以上観察例 27 例については, 発症 5 年後の時点と最近の外来での治 療薬を比較した。

UC の重症度は, Truelove らの重症度分類 ${ }^{1} に$ 準じた 厚生省特定疾患消化吸收障害調查研究班重症度分類 ${ }^{2}$ に したがい, 下痢の回数, 顕血便の有無, 発熱, 頻脈, 貪 血, 赤沈から判定した (Table 2).

難治例の判定は1986年, 厚生省難治性炎症性腸管障害

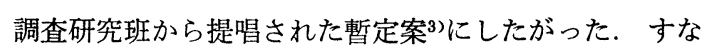
わち難治例の定義は, 厳密な内科的治療下にありなが ら，(1)慢性持続型（初回発作より 6 力月以上活動期にあ るもの), (2)再燃後 6 力月以上なお活動期にあるもの. (3)頻回に再然を繰り返すもの, のいずれかの条件を満た 寸症例とした. このうち(3)の頻回の再燃については, 具 体的には中等度以上の再然が 1 年以内に 2 回以上みられ た場合としだ)。

\section{III. 結 果}

(1) 重症化の時期 (Fig. 1)

重症例は53例中 9 例，延べ12回であった。 そのうち， 発症時, 重症であったものは 4 例, 経過中に重症化がみ られたものは 5 例, 延べ 8 回であった. 経過中に重症化 した例の時期は発症時からいずれも 5 年以内（ 3 力月後 から 4 年 6 力月後), 一方 5 年以降に 重症化した例はな 
Table 1

\begin{tabular}{lccc}
\hline & $\begin{array}{c}5 \text { 年以下 } \\
\text { 観 察 例 }\end{array}$ & $\begin{array}{c}5 \text { 年以上 } \\
\text { 観 察 例 }\end{array}$ & 計 \\
\hline 例 数 & 26 例 & 27 例 & 53 例 \\
男女比 & $1: 1.2$ & $1: 2.4$ & $1: 1.7$ \\
発症時年齢 & $14 \sim 69$ 歳 & $15 \sim 58$ 歳 & $14 \sim 69$ 歳 \\
(平均年龄) & $(35.2$ 歳) & $(32.7$ 歳) & $(33.9$ 葴) \\
経過観察月数 & $4 \sim 60 \mathrm{M}$ & $66 \sim 216 \mathrm{M}$ & $4 \sim 216 \mathrm{M}$ \\
(平均月数) & $(31.1 \mathrm{M})$ & $(113.9 \mathrm{M})$ & $(73.2 \mathrm{M})$ \\
\hline
\end{tabular}

Table 2

\begin{tabular}{|c|c|c|}
\hline & 重症 & 軽症 \\
\hline 1) 下痢 & 6 回以上 & 4 回以下 \\
\hline 2) 顕血便 & $(+++)$ & $(+)-(-)$ \\
\hline 3）発熱 & $37.5^{\circ} \mathrm{C}$ 以上 & $(-)$ \\
\hline 4) 頻脈 & $90 /$ 分以上 & $(-)$ \\
\hline 5）貧血 & $\mathrm{Hb} 10 \mathrm{~g} / \mathrm{dl}$ 以下 & $(-)$ \\
\hline 6）赤沈 & $30 \mathrm{~mm}$ ( 1 時間値)以上 & 正常 \\
\hline
\end{tabular}

1. 重症；1）扰よ゙ 2)の他に全身症状である 3)または 4) のいずれかを満たし，かつ 6 項目のうち 4 項目を満たす あの.

2. 軽症； 6 項目すべて満たすすの.

3. 中等症 ; 上記の重症と軽症との中間にあたるもの.

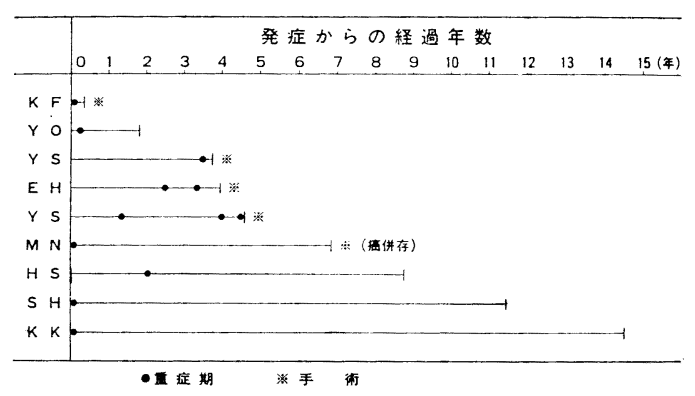

Fig. 1 重症化の時期

かった. 重症例 9 例中 5 例に手術が適応された.

（2）難治化の時期（Fig. 2)

難治例は 53 例中 10 例で, その内訳は(1)慢性持続型 3 例 (症例11, 症例 3 , 症例14), (2)再燃後 6 力月以上活動期 型 3 例（症例10，症例4，症例7），(3)頻回再燃型 6 例（症 例 12 , 症例 4 , 症例 5 , 症例 13 , 症例 7 , 症例 9 ) であっ た.このうち 2 例洅再燃後 6 力月以上活動期型でもあっ た. 難治化の時期は発症 6 力月後から10年後（平均 4.4 年後）と広範囲にわたったが，8例では発症 2 年以内に 難治化し，5年以降に難治化した例は 10 年後に難治化し た1例のみであった．10例中 5 例に手術が適応された.

(3) 手術時期と手術適応理由（Fig. 3)

当教室における手術例は 7 例で，いずれも重症化例

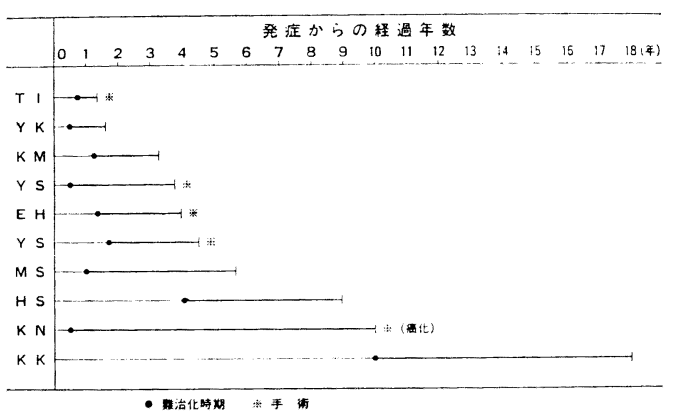

Fig. 2 難治化の時期

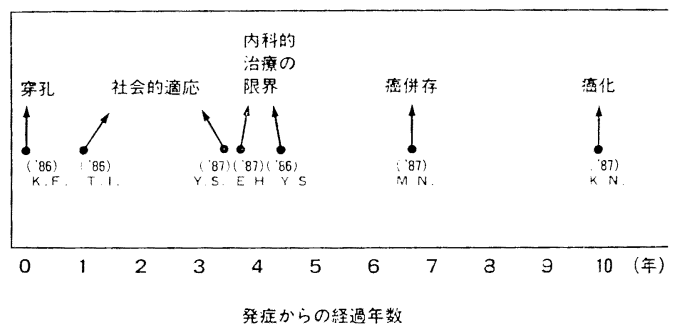

Fig. 3 手術適応理由

（症例 1, 症例 3 , 症例 4 , 症例 5 , 症例 6) (Fig. 1) および難治化例（症例 10, 症例 3 , 症例 4 , 症例 5 , 症 例14）(Fig. 2) であった。すなおち重症化例 2例，難 治化例 2 例, 重症かつ難治化例が 3 例であった。 7 例中, 発症 5 年以内の手術施行例は 5 例と大部分を占め, 手術 適応理由は穿孔 1 例 (発症 3 力月後), 社会的適応 2 例 (発症 1 年 4 力月後, 3 年 9 力月後), 内科的治療の限界 を超えたもの 2 例 (発症 3 年 10 力月後, 4 年 7 力月後) であった。一方, 発症 5 年以上経過した手術例は 2 例 で, 手術適応理由は癌併存（発症 6 年10力月後）上癌化 (発症10年後) であった。

（4）入院時の重症度（Fig. 4，5）

発症時㧍よび経過中に入院した例は50例，入院回数㳉 延心゙94回であった (Fig. 4).これらを発症 5 年以内上 5 年以上にわけた場合, 発症 5 年以内入院例 49 例（延心 83回）では重症例 $14.5 \%$, 中等症例 $47.0 \%$, 軽症例 26.5 $\%$, 一方, 5 年以上の 7 例(延べ 11 回)では, 重症例 $0 \%$, 中等症例 $72.7 \%$, 軽症例 $27.3 \%$ であり, 発症 5 年以内の 入院例で重症例の頻度が高い傾向がみら礼た。

Fig. 5 は入院時の重症度を年度別に示したものであ る.

(5) 発症からの経過年数別入院回数, 入院月数 (Table 3)

入院例を, 発症 5 年以内の 49 例と 5 年以上の 7 例にわ けた場合，延べ入院回数はそれぞれ 83 回，11回，延べ 


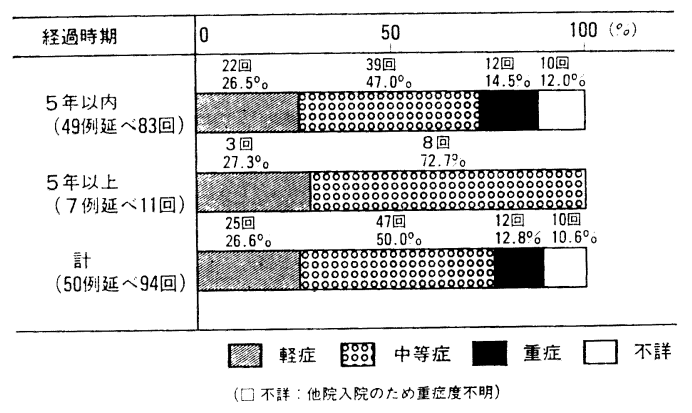

Fig. 4 人院時の重症度

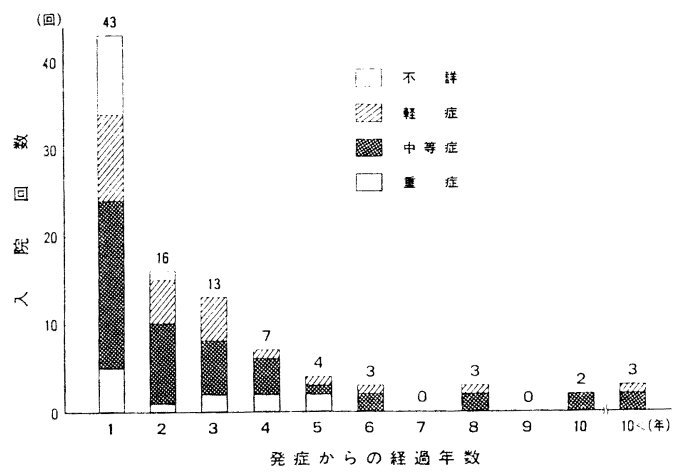

Fig. 5 入院時の重症度

Table 3

\begin{tabular}{lcc}
\hline 発症からの年数 & 5 年以内 & 5 年以降 \\
\hline 症例数 & 49 & 7 \\
延べ入院回数 & 83 & 11 \\
延べ入院月数 & 244 & 26 \\
延へ観察月数 & 2428 & 1454 \\
1 症例あたりの入院回数 & 1.69 & 1.57 \\
1 症例あたりの 1 回の平均入院月数 & 2.9 & 2.4 \\
延べ入院月数 & 0.10 & 0.02 \\
\hline 延べ観察月数 & & \\
\hline
\end{tabular}

入院月数は 244 力月, 26 力月, 延べ観察月数は 2,428 力 月，1,454力月であった。この結果を 1 症例あたりでみ ると, 入院回数はそれぞれ1.69回，1.57回，平均入院月 数は 2.9 力月, 2.4 力月, 延べ入院月数/延へ観察月数沫 $0.10,0.02$ であった。 すなわち発症 5 年以内と 5 年以降 を比較した場合, 入院回数, 平均入院月数にほとんど差 はなかったが, 観察期間に対する入院期間の比率は後者 で著しく短かった。

\section{(6) 入院率 (Fig. 6)}

年次別入院率は発症 1 年目は 53 例中 41 例 $(77.4 \%)$ と きわめて高頻度であったが， 2 年目は51例中15例（29.4 $\%$ ）と激減，それ以降は 5 年目 31 例中 3 例 $(9.7 \%$ ) と

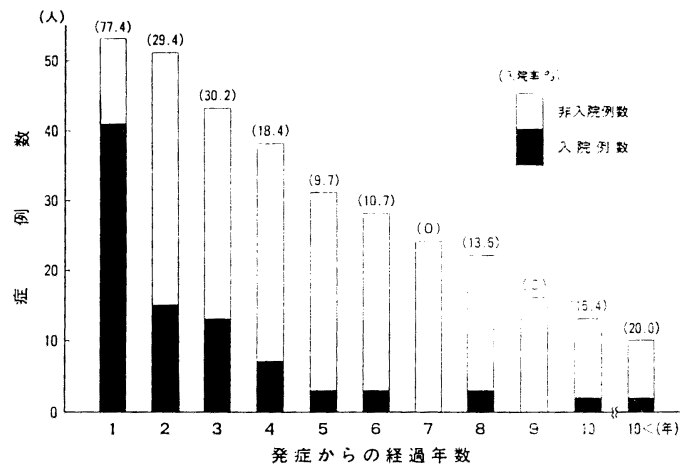

Fig. 6 入院率

Table 4

\begin{tabular}{|c|c|}
\hline 治療薬の減少例 & 10例 \\
\hline 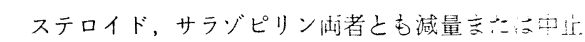 & 3 例 \\
\hline ステロイドのみ隇量または中止 & 5 例 \\
\hline サラゾピリンの滅量または中止 & 2例 \\
\hline 治療薬の増加例 & 4 例 \\
\hline ステロイド, サラン゙ピリン汕者とあ増量 & 1例 \\
\hline ステロイドのみ増量 & 3例 \\
\hline 不＼cjkstart变 & 13例 \\
\hline 計 & 27例 \\
\hline
\end{tabular}

漸次低下した。発症 5 年以降の入院率洁 $0 \sim 20 \%$ の間を 增減した.

（7） 5 年経過時点と最近の外来治療での治療薬の比較 (Table 4)

5 年以上経過観察例 27 例につき, 5 年経過時点と最近 の外来治療の薬物療法につき比較した. 発症 5 年以降, 治療薬が減少した例は10例で，ステロイド，サラゾピリ ン両者とも減量または中止 3 例, ステロイドのみ減量ま たは中止 5 例, サラゾピリンのみ減量または中止 2 例, 一方治療薬が増加した例は 4 例で, ステロイド, サラジ ピリン両者とも増量 1 例, ステロイドのみ増量は 3 例で あった. 残りの13例の投薬量は不変であった.

\section{IV. 考 察}

重症 UC では, ステロイド強力静注療法 ${ }^{5}$, 動注療 法5)などの処置がなされるが, 無効の場合, 手術が適応 される. 今回のわれわれの検討では，重症例 9 例，延べ 12例ではいずれも発症 5 年以内に重症化した。このう ち, 3 例（症例 3 , 症例 4 , 症例5）漠佁治例でもあり手 術が適応された. 一方重症例でも, 症例 7 , 症例 8 , 症 例 9 の 3 例のように内科的治療によって改善し, その後 
1 回も入院を必要とせず, 外来のみで管理可能であった 症例もあった.

UC 難治例については，1983 年日本消化器病学会 work shop で取りあげられ6-9)，その後1986年，厚生省 難治性炎症性腸管障害調査研究班から 暫定的に 難治性 UC の基準案が提唱され，それに基いて数施設よりその 実態が報告されている10-13)が，発症時期と関連つけた報 告はない. 今回のわれわれの検討では，10例中 9 例が 5 年以内（うち8 例は 2 年以内）に難治化した. 教室の難 治例で, 内科的治療を行ったものでは現在までのところ 非難治例への移行がみられた症例がなかったこと, 難治 例では緩解しても長期にわたって緩解を維持することが 困難であったことからみて, 難治例で治療抵抗性のもの に対して早期に手術を選択する考えは, 十分首肯できる ものと思われる. 今回教室例の検討では, 10例中 5 例で 手術が適応された. 大川ら ${ }^{14)}$ は全国から集計した難治性 UC 115 例の検討から, 手術施行例および手術を考慮中 の症例は 59 例 $(51 \%)$, 現在のところ手術を考虑してい ない症例 42 例 $(37 \%)$, 内科的治療で軽快した症例は 11 例（9\%）であったと報告し，難治性 UC で高率に手術 が適応されたことを強調している.

教室の手術例は, 癌化, 癌合併によるものを除くと, 手術が適応されたのは内科的治療の限界を超えたもの 2 例, 社会的理由によるもの 2 例, 穿孔を起こしたもの 1 例であり，発症から手術までの期間は平均 2.7 年であっ た。一方，田島ら ${ }^{15)}$ は手術施行例は UC 189 例中13例 で, 手術理由は内科的治療に抵抗した例が 7 例と最む多 く, そのほか社会的適応 2 例. 大量出血 2 例, 狭窄 1 例 であり，発症から手術までの期間は平均約 2 年とわれわ れの報告とほぼ同様であった．また Bonnevie ら ${ }^{16)}$ は, 癌化例を除いた手術施行例56例を検討した結果，19歳以 下の症例を除くと，ほとんどの例は診断 4 年以内に手術 されたと述べている. 癌化, 癌合併を含めた教室の全手 術症例 7 例の発症から手術までの期間は, 平均 4.4 年で あった. このことは武藤ら ${ }^{17}$ の1973年〜 1985年の癌化, 癌合併例を含む UC 手術例239例の集計結果（手術まで の期間 4.8 年）とほぼ一致した.このように癌化の問題 を除くと, UC では発症 5 年以内にほとんどの例で手術 が行なわれている。一方，本邦における UC 合併大腸 癌報告例 64 例の癌発生時期は, UC 発症後 $5 \sim 10$ 年が 10 例 $(15.6 \%) ， 10$ 年以上が 44 例 $(68.8 \%)$ であり ${ }^{18)}, 5$ 年 以上経過 UC 症例では cancer surveillance が最も重 要な問題と考えられた.

UC 発症後の推移を, 経過年数と結びつけて検討した 報告は比較的少ない.Ritchieら ${ }^{19)}$ は UC 例を11年間経 過観察した結果, その多くは発症 1 年以内に入院したと
述べ，一方，井上ら ${ }^{20}$ は初診時からの経過年数が長くな るほど緩解率が増加したこと, 宇都宮ら ${ }^{21)} 5$ 年以上経 過したものでは, “緩解” “受診せず”のものが増加した と報告している. われわれは教室の UC 症例を発症 5 年以内と 5 年以上にわけて入院時の重症度を検討した結 果, 5 年以上の入院例はすべて軽症, 中等症で, 重症例 はなかった。.また発症 5 年以降の症例では観察期間に対 する入院期間の比率が 5 年以内の症例に比較して極めて 短かった．また 5 年以上経過した場合, 投与された治療 薬も減少する例が多かった。この点からも，UC で重症 化, 難治化, 手術適応などが問題となるのは, 発症 5 年 以内で, 一方， 5 年を経過すると，管理は比較的容易で あることが示された。

発症 5 年以上経過例で, 管理が比較的容易になる理由 としては，UCの病勢それ自体が経過と共に緩徐になる ことのほか, (1)手術が適応された重症例, 難治例が経過 観察例から除かれること, (2)患者自らが病状を把握し自 己管理が可能になること，などもあげることができよ 5 .

以上, UC 例の管理は発症 5 年以内が最も重要であ り，5年以上の経過観察例では，癌化に対する cancer surveillance が重要な課題と考えられた.

\section{V. 結 論}

当教室で経験した UC 53例について重症例, 難治例 の手術適応を, 発症よりの経過年数と関連づけて検討し た. また入院率と経過年数との関係についても検討し た. その結果, 発症 5 年以内は, 重症化, 難治化, 手 術適応の問題に留意すること， 5 年以上経過した例では cancer surveillanceに留意することが肝要と思われた.

この研究の一部は, 厚生省難治性炎症性腸管障害調查 研究班（班員正宗 研）の研究費によった。

\section{文献}

1) Truelove SC, Witts LJ : Cortisone in ulcerative colitis-Final report on a therapeutic trial. Brit Med J 2: 1041-1048, 1955

2) 吉田 豊: 潰瘍性大腸炎重症度分類. 厚生省特 定疾患消化吸収障害調查研究班 昭和 60 年度業 績集 26-27, 1986

3) 井上幹夫 : 班長総括. 厚生省特定疾患難治性炎 症性腸管障害調查研究班, 昭和61年度業績集 27-30, 1987

4）飯塚政弘, 千葉満郎, 堀江泰夫ほか: 難治性潰 瘍性大腸炎一教室例の検討一. 日本大腸肛門病 会誌 $42: 94-98,1989$

5）井上幹夫：潰瘍性大腸炎薬物療法指針の改訂. 厚生省特定疾患消化吸収障害調查研究班, 昭和 
60年度業績集 $\quad 17-18,1986$

6）秋本 伸, 浜野恭一：潰瘍性大腸炎難治例の手 術適応. 日消病会誌 $80: 1821,1983$

7）北野厚生, 小林絢三：難治性潰瘍性大腸炎の治 療一教室における長期経過追求例を中心とし て一。 日消病会誌 $80: 1821,1983$

8）喜田 剛, 田島 強: 難治性潰瘍性大腸炎の治 療. 日消病会誌 $80: 1822,1983$

9）千葉満郎, 棟方昭博: 潰瘍性大腸炎重症例, 緩 解導入遷延例，易再燃例の手術への関わりにつ いて. 日消病会誌 $80: 1823,1983$

10）守田則一，萇田智憲，塩飽徳行ほか：いわゆる 難治性潰瘍性大腸炎の臨床統計について，厚生 省特定疾患難治性炎症性腸管障害調查研究班, 昭和61年度業績集 $\quad 148-150,1987$

11）山村誠, 山本一成, 中村正樹ほか：教室にお ける難治性潰瘍性大腸炎の検討一粪便細菌叢と カルボン酸を中心として一。 日本大腸肛門病会 誌 $40: 595,1987$

12）小林絢三，北野厚生，大川清孝ほか：難治性潰 瘍性大腸炎の臨床的検討. 厚生省特定疾患難治 性炎症性腸管障害調查研究班, 昭和61年度業績 集 $174-175 ， 1987$

13）村田有志, 高橋 修, 石塚圭輔ほか：難治性潰 瘍性大腸炎の臨床的検討. 日本大腸肛門病会誌 $40: 596,1987$

14）大川清孝, 北野厚生, 小林絢三 : 難治性潰瘍性 大腸炎アンケート調查報告 成績と分析結果
(第 1 報). 厚生省特定疾患難治性炎症性腸管障 害調査研究班, 昭和62年度業績集 54-64, 1988

15）加藤久美子, 田島 強 : 潰瘍性大腸炎の長期経 過, 結腸炎型と直腸炎型の対比を中心として. Gastroenterol Endsc 27 : 2178-2179, 1985

16) Bonnevie $O$, Vibeke Binder, Anthonisen $P$ et al: The prognosis of ulcerative colitis. Scand J Gastroent 9:81-91，1974

17）武藤徹一郎：外科治療分科会長報告. 厚生省特 定疾患難治性炎症性腸管障害調査研究班, 昭和 62年度業績集 $65-82 ， 1988$

18）児玉 光，五十嵐潔，鶴居信昭ほか：潰瘍性大 腸炎に合併した大腸癌の 2 例. Gastroenterol Endsc 31 : 1325-1335, 1989

19) Ritchie JK, Powell-Tuck J, Lennard-Jones $\mathrm{J}$ : Clinical outcome of the first ten years of ulcerative colitis and proctitis. Lancet 1 : 1140-1142, 1978

20）井上幹夫，吉田一郎：潰瘍性大腸炎の内科的治 療およびその経過について，厚生省特定疾患 消化吸収障害調查研究班, 昭和 59 年度 業績集 227-234, 1985

21）宇都宮利善，吉田武士，高浪簏ほか：潰瘍 性大腸炎 (idiopathic procto-colitis) の疫学的 研究報告（第11報），厚生省特定疾患消化吸収 障害調査研究班，昭和60年度業績集 265-273， 1986

\title{
Characteristics of Ulcerative Colitis Relating to the Time Since the Onset
}

\author{
Y. Horie, M. Chiba, M. Iizuka, K. Igarashi and O. Masamune \\ The First Department of Internal Medicine, Akita \\ University School of Medicine, Akita, Japan
}

Characteristics of ulcerative colitis were investigated in fifty-three patients in relating to the time since the onset of the disease. The following results were obtained. (1) All 12 severe ulcerative colitis in 9 patients became severe type in less than 5 years since the onset. (2) All 9 intractable cases except for one case became intractable in less than 5 years since the onset. (3) Surgical intervention was performed in 7 patients. Five of these were done in less than 5 years since the onset and the remaining two cases were done for colon cancer after 5 years. (4) The ratio of admission time to observation time was significantly larger in patients less than 5 years since the onset compared to those more than 5 years. (5) Admission rate was 77.4 per cent $(41 / 53)$ in the first year since the onset. It was decreased gradually year after year and 9.7 per cent at 5 year since the onset. It was stationary thereafter. These results indicated that, in patients less than 5 years since the onset, therapy should be devoted to prevent from developing severe type or intractable case and to judge a proper time for surgical intervention, while in patients more than 5 years, cancer surveillence is important. 